\title{
Sejr til EU i sagen om profet-satiren Torben Krogh
}

\section{UNESCO blev det første FN-organ, hvor den}

muslimske verden forsøgte at få begrænset ytringsfriheden i religionens navn. Sammenhold blandt de 25 EU-lande sikrede - på tværs af interne meningsforskelle - et tilfredsstillende kompromis

På forårssamlingen i UNESCOs styrelsesråd flyttede konflikten om de satiriske tegninger af profeten $\mathrm{Mu}$ hammed for alvor fra demonstrationernes, handelsboykotternes og ambassadeafbrændingernes konfrontatoriske verden til den multilaterale, diplomatiske scene. Organisationen for den Islamiske Konference (OIC) mente - ganske forståeligt - at FN's særorganisation for uddannelse, videnskab, kultur og kommunikation var det rette forum for en behandling af denne sag. Så allerede i februar sørgede de for, at den blev indskrevet på rådets dagsorden. Styrelsesrådet er UNESCOs eksekutive organ, valgt af generalkonferencen, men trods sine funktioner har det ikke færre end 58 medlemsstater. Hvad der bliver vedtaget i styrelses- rådet vil derfor normalt blive til UNESCOs officielle politik

Med OIC's udspil blev der lagt op til den alvorligste konfrontation i UNESCO siden den store konflikt $\mathrm{i}$ 1980'erne om “den nye verdensinformations- og kommunikationsorden”. Nu som dengang var det ytringsfrihedens grundprincipper, der stod i centrum. I 1989 lykkedes det de demokratiske samfund at vinde et hårdt og opslidende slag med en række militante ulande og den hensygnende Sovjet-blok. I den nye strid stod de muslimske lande for det synspunkt, at ytringsfriheden kan og bør underordnes andre hensyn, fordi disse hensyn - især de religiøse er mere tungtvejende i samfundslivet, det nationale såvel som det internationale. 
I samfund med en grundfæstet demokratisk styreform er denne betragtning blevet besvaret med en klar afvisning - men med den tilføjelse, at ytringsfrihedens ukrænkelighed ikke er ensbetydende med, at den er ubegrænset. Det er som regel lovstridigt at krænke privatlivets fred, at vanære navngivne personer, at offentliggøre statshemmeligheder, at ytre sig racistisk og - af særlig betydning i dette tilfælde - at fremsætte blasfemiske udsagn.

I den forbindelse er der i alle demokratier lovfæstede ansvarsbestemmelser, der kan gøres gældende ved en domstol. Afgørende her er det imidlertid, at der ikke sker nogen form for forhåndscensur. Samtidig er der i disse sammenhænge tale om lovbestemmelser, der er blevet klart anerkendt som et anliggende for den enkelte nationalstat.

\section{Delte meninger i EU}

I det første udspil fra OIC blev der ganske utvetydigt lagt op til en vedtagelse, der ville underordne ytringsfriheden i relation til omtalen af religiøs tro og religiøse symboler. De muslimske lande arbejdede med en idé om, at der burde vedtages en international konvention med et sådant indhold. Ganske vist brugte de ikke direkte ordet konvention, men talte i stedet om "en mekanisme". Hensigten var, at UNESCO skulle være rammen for forberedelse, udarbejdelse og vedtagelse af en sådan konvention. Samtidig stod det klart, at nogle OIC-lande ville bruge UNESCO som en form for generalprøve på det initiativ, de har planer om at lancere på efterårets generalforsamling i FN.

Tidligt i forløbet efter det første udspil fra OIC besluttede EU-landene at forsøge sig ad forhandlingernes vej. Nogle var imidlertid mere skeptiske end andre. Især var Frankrig, Danmark og Europa-Kommissionen bange for, at der kunne blive givet for store indrømmelser. Men også lande som Storbritannien, Holland, Finland og Sverige gjorde klart, at der var en grænse for, hvad de ville gå med til.

At Frankrig her optrådte som Danmarks nærmeste allierede kunne måske umiddelbart undre. Det er ingen hemmelighed, at de franske politiske ledere fandt den danske regerings - og især statsministerens håndtering af sagen ualmindelig klodset. Det har præsident Jacques Chirac nærmest sagt direkte.

Men i denne sammenhæng var det andre hensyn, der vejede tungere. Et af de mest grundfæstede principper i den franske republik er den totale adskillelse mellem stat og kirke. Derfor byder det Frankrig dybt imod, at interstatslige organisationer bliver brugt til at regulere forholdet mellem lovgivning og religiøs tro. Andre EU-lande - især, men ikke udelukkende de næsten rent katolske har tradition for et tæt forhold mellem stat og kirke. De for- 
skellige standpunkter kom meget klart til udtryk, da udkastet til en forfatningstraktat for EU i sin tid skulle forhandles færdigt.

\section{Kimen til konflikt}

En tilsvarende spredning i grundholdningerne eksisterer ikke blandt de muslimske lande. I den islamiske tradition er båndet mellem stat og religion tæt, også i de lande, der ifølge deres forfatning er sekulære. Det hindrer dog ikke, at der hersker meget betydelige forskelle blandt de 57 nationer, der er med i OIC. Denne organisation betragtes generelt som en diskussionsklub snarere end som rammen om operative initiativer. Imidlertid gav det god mening, at netop den blev valgt til ramme for fremstødet i UNESCO.

For det første angår selve sagen religiøse anliggender. Og for det andet opnåede de mest ivrige muslimske lande på den måde at få den bredest mulige platform. OIC omfatter store og betydningsfulde lande i Asien, hele den arabiske verden og adskillige afrikanske lande syd for Sahara. Blandt medlemslandene er også nationer, hvor muslimerne ikke udgør noget flertal, men dog en betydelig del af samfundet. Det mest iøjnefaldende eksempel er Indien, der på sidelinjen spillede en betydningsfuld rolle under forhandlingerne i Paris. Som USA i øvrigt også gjorde på de vestlige landes side.
Ved udgangen af marts fremlagde OIC-landene deres officielle begrundelse for at forlange sagen på styrelsesrådets dagsorden. I den skrev de, at "respekt for ytringsfrihed og respekt for religiøs tro og religiøse symboler er to uadskillige principper og går hånd $\mathrm{i}$ hånd $\mathrm{i}$ kampen mod uvidenhed og mod manglen på forståelse". De slog endvidere fast, at ytringsfrihed bør udøves med en dyb ansvarsfølelse og i respekt for religioner, tro og overbevisning.

Det operative afsnit i det resolutionsforslag, OIC-landene samtidig fremlagde, rummede kimen til den mest alvorlige konflikt i UNESCO siden 1989. De ønskede, at generaldirektør Koïchiro Matsuura skulle indlede forberedelser til "vedtagelsen af et internationalt instrument til at sikre alles respekt for religiøs tro og religiøse symboler". Og de lagde op til, at det skulle ske så hurtigt som muligt. Allerede ved forårssamlingen i 2007 skulle generaldirektøren fremlægge resultatet af det forberedende arbejde.

\section{Hård muslimsk udgangsposition}

Her gik grænsen for EU-landene. Under ingen omstændigheder kunne de acceptere, at UNESCO skulle bruges som ramme for en sådan konvention. Var sagen kommet til åben afstemning, er der ingen tvivl om, at OIC-landene havde kunnet mobilisere et flertal. Men det afstod 
de fra, vel vidende at en konvention, som ville være uden udsigt til at blive ratificeret af den vestlige verden plus en hel del andre - kun kunne blive et slag i luften.

Samtidig spillede det en væsentlig rolle, at traditionen for beslutningstagen i UNESCO igennem de seneste tre årtier har været baseret på konsensus-princippet. Afstemninger, hvor et flertal stemmer et mindretal ned, betragtes i denne politisk-diplomatiske kultur som en form for nederlag for alle.

Men ville det også være tilfældet i netop denne sag? Længe stod spørgsmålet åbent blandt de europæiske repræsentationer. Ikke blot retorikken, men også attituden var hård blandt de muslimske lande. De satiriske tegninger var en dybt krænkende grænseoverskridelse af religiøse værdier og almindelig anstændighed. Enhver gentagelse måtte forhindres, så langt det ville være muligt igennem en bindende international konvention.

Samtidig var OIC-landenes adfærd dog også præget af en god gang realpolitik. Det kom ikke mindst til udtryk i den delegation, de sendte til de fortrolige forhandlinger med EU's repræsentanter. De muslimske forhandlere kom fra Pakistan, Senegal, Tyrkiet og Yemen, hvilket vil sige fire lande med et sekulært, politisk styre.

Nok spiller islam betydelig rolle i disse lande - dog i langt højere grad i fx Pakistan end i Senegal. Men på ingen måde er der tale om en statsreligion som i Saudi-Arabien eller Iran. I alle fire lande har det høj prioritet for den politiske magt at holde fundamentalistiske strømninger i ave. $\mathrm{Og}$ i varierende grad er der faktisk også tale om samfund med en demokratisk - eller delvis - demokratisk styreform.

\section{Sejr for ytringsfriheden}

Sammensætningen af denne forhandlingsdelegation afspejlede for det første de mere sekulære OIClandes beslutning om at sætte sig på denne sag og for det andet et ønske om over for EU at signalere imødekommenhed. I den forbindelse var det især værd at lægge mærke til, at Tyrkiet var blandt de muslimske forhandlere.

I en konsensus-tradition bliver der ikke udråbt vindere og tabere. Men en nøgtern analyse af det resultat, der den 13. april blev vedtaget af det samlede styrelsesråd, kan kun munde ud i en konklusion, som kilder i UNESCO-diplomatiet straks satte ord på: De muslimske lande havde bevæget sig længst for at sikre et kompromis. I den endelige tekst er der ingen henvisninger til nogen form for "mekanisme", et internationalt "instrument" eller en konvention. Og princippet om ytringsfrihedens ukrænkelighed står uantastet. Det bliver ikke på nogen måde underordnet hensynet til religiøs tro eller religiøse symboler. 
De muslimske lande måtte tage til takke med gentagne henvisninger til gensidig respekt for religiøse og kulturelle værdier, religiøs tro og religiøse symboler. Instruksen til UNESCOs generaldirektør blev indskrænket til at handle om en grundig analyse af alle eksisterende internationale instrumenter og til at "foreslå midler og handlemuligheder for UNESCO til at fremme gensidig forståelse for at fjerne det stadigt eksisterende ukendskab til andres livsformer og adfærd".

Alt, hvad der kunne betegnes som politisk forkasteligt for de grundfæstede demokratier, var med andre ord trukket ud af teksten. Da de muslimske lande ikke desto mindre erklærede sig tilfredse med resultatet, blev det med god grund betragtet som et gennembrud for fornuftens diplomati i en sag, der både $\mathrm{i}$ Europa og den muslimske verden har fremkaldt de mest intense følelser. Det betyder dog ikke, at sagen dermed er slut i FN-systemet. Det er en udbredt antagelse, at nogle OIClande har brugt UNESCO som en scene for generalprøven på det beslutningsforslag, de vil introducere på FN's generalforsamling i efteråret.

Hvis det holder stik, har vedtagelsen i UNESCOs styrelsesråd imidlertid forsynet modstanderne af en sådan bestræbelse med en værdifuld platform. 